\title{
Effect of Rock Phosphate, Herbicides Particles and Phosphate Solubilizing Bacteria on Growth and Chemical Composition of Corn Plants Grown in Calcareous Soil
}

\author{
Hussein, M. A ${ }^{1}$, A. Abdel-Mageed ${ }^{2}$, M. A. Sabra ${ }^{3}$, and A. A. E. Nasr ${ }^{4}$ \\ ${ }^{1}$ Soil and Agric. Chemistry Dept. Faculty of Agriculture (Saba- Basha) Alexandria \\ University. \\ ${ }^{2}$ Plant Protection Dep. Faculty of Agriculture (Saba- Basha) Alexandria University. \\ ${ }^{3}$ Agriculture, Botany Dept. Faculty of Agriculture (Saba- Basha) Alexandria University \\ ${ }^{4}$ Postgraduate student
}

\begin{abstract}
Pots experiments were conducted on corn plants (Zea mays, L.), Trihybrid 302 , at the experimental greenhouse of the Agriculture Faculty (Saba-Basha), Alexandria University, Egypt to evaluate the effect of rock phosphate, some nano-herbicides particles and phosphate solubilizing bacteria on growth and chemical composition of corn plants grows in calcareous soil. The experiment was designed as spilt -spilt plot design with four replicates. Each replicate contained 8 treatments as follows: main plot as rock phosphate $(0,50$ and 100), subplot as herbicides (Control, herbicide, nano-herbicide), sub-sub plot phosphate solubilizing bacteria (Uninoculated, Bacillus megaterium). Results indicated that, the interaction with rock phosphate at a rate $100 \%$ of the recomonded dose and nano-herbicides in the case of plants inoculated with $B$. megaterium bacteria recorded the maximum mean values of vegetative growth of maize (plant height, total chlorophyll (SPAD), shoot fresh weight, shoot dry weight, leaf area index, as compared of control plants which gave the minimum mean values of these characters. Also, rock phosphate at $100 \%$ rate, nano-herbicides and bacteria gave the highest mean values of root fresh and dry weight, as compared with control. Moreover, rock phosphate at $100 \%$ rate, nano-herbicides and bacteria gave the highest mean values of $\mathrm{N}, \mathrm{P}, \mathrm{K}$ percentages in shoot, as compared with control.
\end{abstract}

Keywords: Bacillus megaterium, Nano-herbicids, phosphate solubilizing bacteria , Rock phosphate (RP).

\section{INTRODUCTION}

Phosphorus $(P)$ is one of the key components required for plant development and growth; it makes up about $0.2 \%$ of the dry weight of the plant. It is the major element second among the mineral nutrients most widely used to limit crop development (Azziz et al., 2012) and plays a vital role in plant productivity and metabolism by providing the energy needed for metabolic mechanisms (Elser et al., 2007) The majority of soils like arid and semiarid regions are deficient in available phosphorus (Memon et al., 1992, Kang et al., 2011). The availability of $P$ is affected by soil chemical properties and human management activities.

Inorganic $\mathrm{P}$ is mined to produce chemical $\mathrm{P}$ fertilizers that are extensively applied to cropland (Elser and Bennett, 2011; Penuelas et al., 2013). The majority of soluble inorganic $P$, however, is rapidly immobilized by soil fixation and becomes unavailable for plant uptake, leading to low P-use efficiency (Kochian, 2012). Soil $P$ must thus be managed to increase its use efficiency.

Rock Phosphate is a particular word that describes naturally occurring mineral assemblies comprising an elevated concentration of phosphate minerals (Zapata and Roy, 2004). Rock phosphates are generally apatite, 
containing varying percentages of $\mathrm{P}_{2} \mathrm{O}_{5}$ in a calcium matrix, and either directly applied to the soil, in particular in organic farming or in the production of watersoluble phosphorus fertilizers. Sedimentary rock phosphates are reported to be appropriate for direct use as fertilizers only under certain environmental conditions (Chien and Friesen, 2000 and Zapata and Roy, 2004). Microbial production of organic acids and acid phosphatase has important role in mineralizing organic P present in soil (Cherr et al., 2006; Wilhelm et al., 2007).

Phosphate-solubilising bacteria (PSB) inoculants have been assayed but their effectiveness in the soil-plant system is still unclear. In addition, the role of the inoculated PSB that supplies $P$ to the plant seems limited because the transient nature of the compounds released by PSB responsible for phosphate solubilization, and because the possible re-fixation of phosphate ions on their way to the root surface, if any solubilization does take place (Barea et al., 2007). Many researchers proved that PSB plays a key role in soil organic $P$ (Po) transformations (Frossard et al., 1995) through excretion of phosphatase enzymes (Eichler et al., 2004), mineralization of $P$ from organic sources (Gressel and McColl, 1997), and also synthesis and release of Po (Oberson et al., 2001). Besides, microorganisms can solubilize sparingly soluble Pi forms (lyamuremye et al., 1996). Phosphate solubilizing bacteria (PSB) are a group of these microorganisms that can transform insoluble $P$ compounds into available forms by secreting organic acids, and they may be used as inoculants to enhance $P$ availability for plants (Khan et al., 2007). Also, they can promote plant growth via producing hormones, such as cytokinin and indole acetic acid (Coutinho et al., 2012, Zak et al., 2018). Despite some PSB present in plant rhizospheres and soil, the amount of $P$ released by these microorganisms is usually insufficient to meet the demand of growing plants (Collavino et al., 2010). High-efficiency PSB has the potential for making a great contribution to the decrease of environmental pollution and promoting ecological balance by replacing chemical fertilizers (Zak et al., 2018). Consequently, there is an urgent need to investigate the effects of selected high-efficiency PSB on plant nutrition and growth.

During the application of herbicides, a large portion of these chemical accumulates in the top layer soil $(0-15 \mathrm{~cm})$ where most of the microbiological activities occur (Das and Kole, 2006). Microorganisms degrade a variety of carbonaceous substances including the accumulated herbicides in the soil to derive their energy and other nutrients for their cellular metabolism (Das et al., 2003). As a result, the number of microbial biomass increases which favorably influences the transformations of plant nutrients in the soil (Das et al., 2003). Reports are also available (Selvamani and Sankaran, 1993; El-Ghamry et al., 2001) on the deleterious effect of herbicides on growth and activities of microorganisms in the soil. Moreover, the interaction between the herbicides and microorganisms vary depending upon the type of herbicides and microorganisms (Nongthombam et al., 2008).

Current pest management relies heavily on the application of pesticides, such as insecticides, fungicides, and herbicides. In spite of many advantages, like high availability, fast action, and reliability, pesticides have harmful side 
effects towards non-target organisms, the resurgence of the pest population, and the development of resistance (Stephenson, 2003). Furthermore, it is estimated that $90 \%$ of applied pesticides are lost during or after application (Stephenson, 2003; Sinha et al., 2017). As a result, there is an increased motivation to develop cost-efficient, high-performing pesticides that are less harmful to the environment.

Nanotechnology has led to the development of new concepts and agricultural products with immense potential to manage the aforementioned problems. Nanotechnology has substantially advanced in medicine and pharmacology but has received comparatively less interest for agricultural applications (Sinha et al., 2017; Balaure et al., 2017). The use of nanotechnology in agriculture is currently being explored in plant hormone delivery, seed germination, water management, transfer of target genes, nanobarcoding, nanosensors, and controlled release of agrichemicals (Hayles et al., 2017).

Material scientists have engineered nanoparticles with desired characteristics, like shape, pore size and surface properties. So that nanoparticles can then be used as protectants or for precise and targeted delivery via adsorption, encapsulation, and/or conjugation of an active, such as a pesticide (Khandelwal et al., 2016). As agricultural nanotechnology develops, the potential to provide a new generation of pesticides and other actives for plant disease management will greatly increase. The use of nanoparticles to protect plants can occur via two different mechanisms: (a) nanoparticles themselves providing crop protection, or (b) nanoparticles as carriers for existing pesticides or other actives, such as double-stranded RNA (dsRNA), and can be applied by spray application or drenching/soaking onto seeds, foliar tissue, or roots. Nanoparticles, as carriers, can provide several benefits, like (i) enhanced shelf-life, (ii) improved the solubility of poorly water-soluble pesticides, (iii) reduced toxicity, and (iv) boosting site-specific uptake into the target pest (Hayles et al., 2017). The objective of this study was to determine the effect of rock phosphate, some nano-herbicides particles and phosphate solubilizing bacteria on growth and chemical composition of corn plants grows in calcareous soil.

\section{MATERIALS AND METHODS}

This work was carried at the greenhouse of Agricultural Faculty (Saba Basha), Alexandria, Egypt during marc 2019 growing season.

\section{Soil physicochemical characteristics}

Surface calcareous soil sample $(0-15 \mathrm{~cm})$ was collected from Burg Al Arab Alexandria - Egypt. The sample was air-dried, ground to pass into $2 \mathrm{~mm}$ sieve and thoroughly mixed before using. The characteristics of this soil are presented in Table (1).

The methods used for soil analyses were those described by Page et al. (1982). 
Table (1). Some Initial soil physical and chemical properties of the experimental soil

\begin{tabular}{lc}
\hline \multicolumn{1}{c}{ Properties } & Values \\
\hline Mechanical analysis (\%) & \\
Clav & 16.48 \\
Silt & 16.00 \\
Sand & 67.52 \\
Soil texture & Sandy loam \\
pH (1:2 water suspension) & 8.4 \\
EC dsm ${ }^{-1}(1: 1$ water extract) & 4.0 \\
Total CaCO ${ }_{3}(\%)$ & 3.51 \\
Orqanic matter (\%) & 3.01 \\
Soluble Cations (meq/l) & \\
Calcium & $8.5 \mathrm{meq} / \mathrm{l}$ \\
Magnesium & $7.2 \mathrm{meq} / \mathrm{l}$ \\
Sodium & $13.04 \mathrm{meq} / \mathrm{l}$ \\
Potassium & $1.28 \mathrm{meq} / \mathrm{l}$ \\
Soluble Anions (mg/l) & \\
Bicarbonate & 1.20 \\
Chloride & 28.05 \\
Sulphate & 5.37 \\
Total Phosphorus (mg/ kg soil) & 42.5 \\
Available P (mg/ kg soil) & 36.5 \\
\hline
\end{tabular}

\section{Rock phosphate (RP)}

Low- grade rock phosphate sample from a sedimentary phosphate rock deposit supplied in a fine powder to pass through a 400- mesh standard sieve by Al Ahram mining and natural fertilizer Company in Egypt.

\section{Herbicides}

The glyphosate-based herbicide Roundup ( $\mathrm{N}$-(phosphonomethyl) glycine) was used in two forms, the regular form (4g/L) and nanoparticle.

\section{Preparation of nano- glyphosate-based herbicide Roundup}

The nano form of the herbicide was carried out at City of Scientific Research and Technology Applications (SRTA-City). Small quantity of conventical herbicide powders were introduced into the ball milling for further grinding to reach the nano scale of the herbicide. Glyphosate-based herbicide Roundup was undergone and ground using a planetary ball mill (Gj-LC $3210 \mathrm{CH}$ ). The mixed powders together with grinding balls were put into the milling jar with the weight ratio of ball-to-powder of 20:1. Argon was adopted as protective atmosphere of the milling jar. The total milling time was set as $20 \mathrm{~h}$ with each $30 \mathrm{~min}$ resting after $30 \mathrm{~min}$ running to prevent overheating. The particles size of the samples used for performance test was strictly limited between 48 and $72 \mathrm{~mm}$. Figure (1) illusterated (SEM) of nano herbicide showing the nano shape and size at 25000X. 


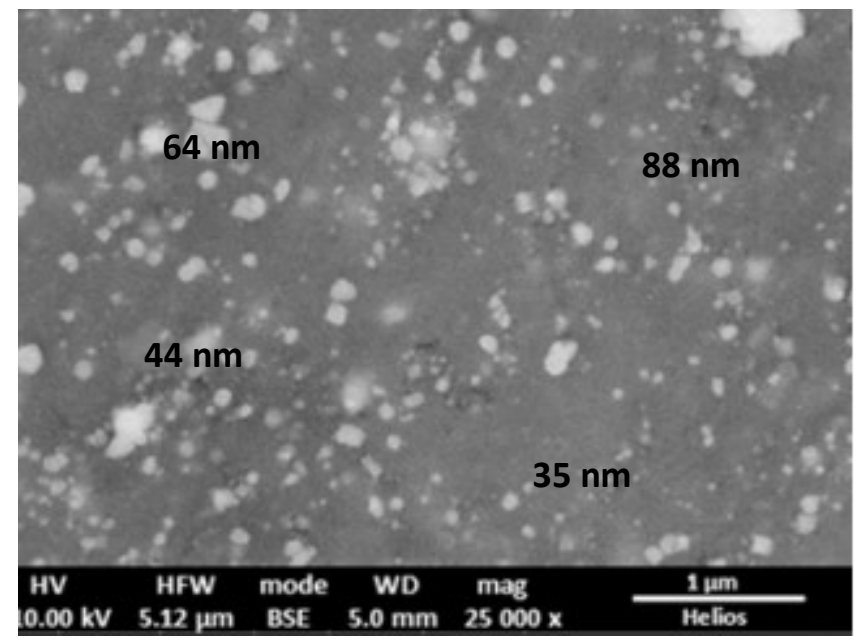

Figure (1). Scanning electron microscopy (SEM) of nano glyphosate showing the nano shape and size at 25000X.

\section{Scanning electron microscopic studies}

Surface morphology of nano- particles was of glyphosate confirmed by scanning electron microscopy (SEM). Analyses of nano- particles were performed using an $\mathrm{H}-7500$ scanning electron microscope (Hitachi, Japan) with an acceleration voltage of $80 \mathrm{kV}$. Nano- particles were imaged after airdrying a droplet on a carbon-coated 200-mesh copper grid. The suspension containing nano- particles were samped by SEM analysis using (JEOL-SEM 100CX) at the electron microscope Unit at City of Scientific Research and Technology Applications (SRTA-City) according to the method described by (Elgorban et al., 2016).

\section{Bacteria inoculum}

Bacillus megaterium, strain 1062, was obtained from the Bio-fertilization unit, Faculty of Agriculture, Ain Shams University, Cairo, Egypt. The bacteria were reproduced on Luria Bertani (LB) medium comprising of $(\mathrm{g} / \mathrm{L})$ tryptone, 10; yeast extract, $5 ; \mathrm{NaCl}, 5$. The $\mathrm{pH}$ of the medium was adjusted to 7.2-7.4 using $1 \mathrm{~N} \mathrm{HCl}$ or $1 \mathrm{~N} \mathrm{NaOH}$ and sterilized by autoclaving at $121{ }^{\circ} \mathrm{C}$ for 15 minutes. The culture was maintained at $30{ }^{\circ} \mathrm{C}$ for 3 days. After seeds germination, bacterial suspension was added to each pot as $15 \mathrm{ml}\left(1.3 \times 10^{6}\right.$ viable cells $\left./ \mathrm{ml}\right)$.

\section{Cultivar}

Corn cultivar, Trihybrid 302, was used in this study. The seeds of this cultivar were obtained from the Agricultural Research Center in Giza, Ministry of Agriculture and Land Reclamation, Egypt.

\section{Pot experiment}

A pot experiment was carried out in the greenhouse at the Faculty of Agriculture (Saba Basha), Alexandria University, Egypt uses the enriched soils with rock phosphate. Plastic pots $(11.5 \mathrm{~cm}$ deep and $17 \mathrm{~cm}$ in diameter) with holes in their bottom) were filled with $2.0 \mathrm{~kg}$ of the enriched soils with three 
levels of rock phosphate $(0,50$ and $100 \%$ of recommended dose) and soil with rock (RP) was mixed at the rate of $9,2 \mathrm{~g} / \mathrm{kg}$ soil as recommended. Seeds of corn Trihybrid 302 cultivar were treated by $0.05 \%$ NaOC1 solution subsequently washed several times with distilled water and planted in each pot.

The experiment was carried out in 3 factors as split - split-plot design with three levels of rock phosphorus $\left(\mathrm{RP}_{0} \%, \mathrm{RP}_{50 \%}\right.$, and $\left.\mathrm{RP}_{100 \%}\right)$ as the main plot. The herbicide treatments control (HP), normal pesticides (HP1), nanopesticides (HP2) \} were randomly distributed in the subplot, While the phosphate solubilizing bacterial treatments \{control (Un-Inoc), Bacillus megaterium (Inoc)\} were arranged in the sub - subplots. The treatments were replicated 4 times Four seeds of corn were planted in each pot and after two weeks, the plants thinned to two plants after emergence. Herbicide were added as (Roundup). The $\mathrm{N}$ fertilizer was applied in three equal does through the growth period at the rate of $50 \mathrm{mg} / 20 \mathrm{ml}$ water for each pot after cultivation. The $\mathrm{P}, \mathrm{K}$, and $\mathrm{Mg}$ fertilizers were applied before filling the pots with soil. All pots were irrigated with tap water every day to keep the soil at $70 \%$ of its field capacity by the regular weighting of pots (Figure 2 ).

\section{Data recorded}

\section{Vegetative parameters}

Two plants per pot were taken to determine the plant height $(\mathrm{cm})$, fresh weight (g/plant). Two plants were air-dried until constant weight and the average dry weight of root and shoot (g/plant) was calculated.

- Plant height (cm/plant).

The average value of plant height was randomly measured per plant in $\mathrm{cm}$.

- Leaf area index.

The LAI was calculated according to Watson (1952) as follows:

$\mathrm{LAI}=\frac{\text { leaf area } / \text { plant }}{\text { plant ground area }}$

- Fresh weight /plant (g).

Plant fresh weight (leaves and stem) was randomly calculated per plant (g).

- Root and Shoot dry weight/plant (g).

The plants per pot were air-dried until constant weight. The average weight was calculated for each sample $(\mathrm{g})$.

\section{Plant analysis}

Plant samples were taken from each pot, at a suitable age washed with running tap water, and then with distilled water. The samples were air-dried, milled and stored for analysis. $0.5 \mathrm{~g}$ of plant powder was wet-digested with $\mathrm{H}_{2} \mathrm{SO}_{4}-\mathrm{H}_{2} \mathrm{O}_{2}$ mixture (Lowther, 1980) and the following determinations were carried out in the digested solution.

\section{Nitrogen content}

Total nitrogen was determined in digested plant material colorimetrically by Nessler's method (Chapman and Pratt, 1978) using $1 \mathrm{ml}$ of Nessler solution $\left(35 \mathrm{~g} \mathrm{IK} / 100 \mathrm{ml}\right.$ distilled water $\left.+20 \mathrm{~g} \mathrm{HgCl}_{2} / 500 \mathrm{ml} \mathrm{d.w}\right)+120 \mathrm{~g} \mathrm{NaOH} / 250 \mathrm{ml}$ d.w. Reading was achieved using wavelength of $420 \mathrm{~nm}$.

$$
\% \mathrm{~N}=\mathrm{NH} 4 \times 0.776485
$$




\section{Phosphorus content}

Total phosphorus in wet ash was determined in the plants by the Vanadomolybdate yellow methodas described by Jackson (1967). Measurement was done using Milton Roy spectronic 21D spectrophotometer.

\section{Potassium content}

Total potassium content was determined according to the method described by Jackson (1967) using Beckman flame photometer.

\section{Concentration index}

Plants were collected after 61 days from planting. Before the harvest time, the Chlorophyll concentration index $(\mathrm{CCl})$ was measured using the chlorophyll meter (Model: CCM-200).

\section{Bacterial media preparation for total count bacteria (cfu)}

According to the literature, the Pikovskaya's agar medium (PVK) was found to be as selective media for the isolation of PSM. The $\mathrm{pH}$ value was maintained at 7. PSM was isolated from each soil sample by serial dilution and spread plate method. One gram $(1 \mathrm{~g})$ of soil sample was dispersed in $9 \mathrm{ml}$ of autoclaved distilled water and thoroughly shaken. $1 \mathrm{ml}$ of the above solution was again transferred to $9 \mathrm{ml}$ of sterile distilled water to form $10^{-2}$ dilution. Similarly $10^{-3}, 10^{-4}, 10^{-5}, 10^{-6}, 10^{-7}$ and $10^{-8}$ serials were made for each soil sample. $0.1 \mathrm{ml}$ of each dilution was spread on Pikovskaya's agar medium (PVK) containing insoluble tricalcium phosphate and incubated at $27-300 \mathrm{C}$ for 7 days. Colonies were counted within the dilution which gave 30-300 colonies.

\section{Statistical analysis}

The collected data were arranged in a randomized complete block design and replicated four times. Data were statistically analyzed for ANOVA and means comparison to fulfill the significance according to Steel and Torrie (1982). A significance level of $\alpha=0.05$ was used in all analysis.

\section{RESULTS AND DISCUSSION}

\section{A) Effect of rock phosphate, herbicides and phosphate solubilizing bacteria on vegetative growth \\ Results presented in Table (2) show the effects of different} concentrations of rock phosphate, phosphate solubilizing bacteria, and herbicides on plant height, stem fresh weight (g), stem dry weight (g) and leaf area index. Concerning the effects of rock phosphate, data indicated that increasing rock phosphate concentrations increased plant height, stem fresh weight $(\mathrm{g})$, stem dry weight $(\mathrm{g})$ and leaf area index ( $\mathrm{LAI})$, as compared with control treatment. Generally, rock phosphate at $100 \%$ rate gave the higher plant height (77.90), stem fresh weight (202.26 g), stem dry weight (40.45 g) and leaf area index (3.88), as compared with control treatment which gave the lowest values of plant height $(51.26 \mathrm{~cm})$, stem fresh weight $(129.44 \mathrm{~g})$, stem dry weight $(25.88 \mathrm{~g})$ and leaf area index (2.48), respectively. Also, the data in Table (2) indicated that nano-herbicides recorded the maximum values of plant height $(78.02 \mathrm{~cm})$, shoot fresh weight $(200.12 \mathrm{~g})$, shoot dry weight $(40.02 \mathrm{~g})$ and leaf area index (3.84), as compared with control treatment which gave the minimum 
values of plant height $(50.75 \mathrm{~cm})$, shoot fresh weight $(131.30 \mathrm{~g})$, shoot dry weight $(26.26 \mathrm{~g})$ and leaf area index (2.52).

On the other hand, inoculation with phosphate solubilizing bacteria recorded the highest mean values of plant height $(67.37 \mathrm{~cm})$, shoot fresh weight (173.16 g), shoot dry weight (34.61 g) and leaf area index (3.32), as compared with control treatment which gave the minimum values of plant height $(60.25$ $\mathrm{cm})$, shoot fresh weight $(155.85 \mathrm{~g})$, shoot dry weight $(31.17 \mathrm{~g})$ and leaf area index (2.99), respectively.

The interaction between rock phosphate and herbicides was high significantly on plant height, stem fresh weight, stem dry weight, and leaf area index, also, the interaction between rock phosphate and phosphate solubilizing bacteria ( $B$. megaterium) was high significantly on plant height, shoot fresh weight, shoot dry weight, and leaf area index. The interaction between herbicides and bacteria was high significantly on plant height, shoot fresh weight, shoot dry weight, and leaf area index, but, the interaction between rock phosphate, herbicides and $B$. megaterium bacteria showed insignificant effect on plant height, shoot fresh weight, shoot dry weight, and leaf area index. Our results are in agreement with those of Han and Lee (2005), who also reported that plant height improves with PSB inoculation over $27 \%$. PSB inoculation improves the availability of minerals content and nutrients which promotes plant growth, increases phosphorus uptake and photosynthesis.

Table (2). Mean effects of rock phosphate, herbicides and phosphate solubilizing bacteria on vegetative growth

\begin{tabular}{|c|c|c|c|c|}
\hline Treatments & $\begin{array}{c}\text { Plant height } \\
\text { (cm) }\end{array}$ & $\begin{array}{c}\text { Shoot fresh } \\
\text { weight (g) }\end{array}$ & $\begin{array}{l}\text { Shoot dry } \\
\text { weight (g) }\end{array}$ & $\begin{array}{l}\text { Leaf area index } \\
\text { (LAl) }\end{array}$ \\
\hline \multicolumn{5}{|l|}{ A) Rock phosphate } \\
\hline Control & 51.26 & 129.44 & 25.88 & 2.48 \\
\hline $50 \%$ & 62.27 & 161.81 & 32.33 & 3.11 \\
\hline $100 \%$ & 77.90 & 202.26 & 40.45 & 3.88 \\
\hline $\operatorname{LSD}(0.05)$ & 2.97 & 0.82 & 0.17 & 0.03 \\
\hline \multicolumn{5}{|l|}{ B) Herbicides } \\
\hline Control (HP) & 50.75 & 131.30 & 26.26 & 2.52 \\
\hline Herbicide(H1) & 62.65 & 162.10 & 32.39 & 3.11 \\
\hline Nano-herbicide (H2) & 78.02 & 200.12 & 40.02 & 3.84 \\
\hline LSD (0.05) & 0.88 & 0.39 & 0.09 & 0.01 \\
\hline \multicolumn{5}{|l|}{ C) PSB } \\
\hline Un-inoculated & 60.25 & 155.85 & 31.17 & 2.99 \\
\hline Inoculated & 67.37 & 173.16 & 34.61 & 3.32 \\
\hline LSD (0.05) & 0.53 & 0.08 & 0.04 & 0.003 \\
\hline \multicolumn{5}{|l|}{ Interaction } \\
\hline$A \times B$ & ** & $* *$ & ** & ** \\
\hline$A \times C$ & ** & ** & ** & ** \\
\hline$B \times C$ & ** & ** & ** & ** \\
\hline $\mathbf{A} \times \mathbf{B} \times \mathbf{C}$ & Ns & ** & ** & ** \\
\hline
\end{tabular}

(Asterisks indicate a significant difference compared to the respective non-inoculated control, according to Tukey's HSD test) 
Perusal data presented in Table (3) revealed that rock phosphate at $100 \%$ rate treatment recorded the maximum root fresh weight $(92.54 \mathrm{~g})$ and root dry weight $(18.50 \mathrm{~g})$, as compared with control treatment which gave the minimum root fresh weight $(59.22 \mathrm{~g})$ and root dry weight $(11.84 \mathrm{~g})$, respectively. It is clear from the date in Table (3) that nano-herbicides significantly increased root fresh weight $(91.56 \mathrm{~g})$ and root dry weight $(18.31 \mathrm{~g})$, as compared with control treatment, which gave the lowest mean values of root fresh weight $(60.15 \mathrm{~g})$ and root dry weight $(12.01 \mathrm{~g})$.

Moreover, the inoculation with phosphate solubilizing bacteria recorded the highest mean values of root fresh weight $(79.23 \mathrm{~g})$ and root dry weight $(15.84 \mathrm{~g})$, as compared with control treatment which gave the minimum values of root fresh weight $(71.36 \mathrm{~g})$ and root dry weight $(14.26 \mathrm{~g})$, succesively.

The interaction between rock phosphate and herbicides were high significant on root fresh weight and root dry weight. Rock phosphate and phosphate solubilizing bacteria, herbicides and phosphate solubilizing bacteria, rock phosphate, herbicides, and phosphate solubilizing bacteria.

Table (3). Mean effects of rock phosphate treatments, herbicides and phosphate solubilizing bacteria (Bacillus megaterium) on root fresh and dry weight

\begin{tabular}{|c|c|c|}
\hline Treatments & Root fresh weight (g) & Root dry weight (g) \\
\hline \multicolumn{3}{|l|}{ A) Rock phosphate } \\
\hline Control & 59.22 & 11.84 \\
\hline $50 \%$ & 74.11 & 14.80 \\
\hline $100 \%$ & 92.54 & 18.50 \\
\hline $\begin{array}{l}\text { LSD (0.05) } \\
\text { B) Herbicides }\end{array}$ & 0.78 & 0.15 \\
\hline Control $(\mathrm{H} 1)$ & 60.15 & 12.01 \\
\hline Herbicide (H2) & 74.16 & 14.83 \\
\hline Nano-herbicide (H3) & 91.56 & 18.31 \\
\hline LSD (0.05) & 0.43 & 0.07 \\
\hline \multicolumn{3}{|l|}{ PSB(Bacillus megaterium) } \\
\hline Un-inoculated & 71.36 & 14.26 \\
\hline Inoculated & 79.23 & 15.84 \\
\hline $\operatorname{LSD}(0.05)$ & 0.15 & 0.15 \\
\hline \multicolumn{3}{|l|}{ Interaction } \\
\hline$A \times B$ & ** & $* *$ \\
\hline$A \times C$ & ** & ** \\
\hline$B \times C$ & ** & $* *$ \\
\hline$A \times B \times C$ & ** & $* *$ \\
\hline
\end{tabular}

(Asterisks indicate a significant difference compared to the respective non-inoculated control, according to Tukey's HSD test) 


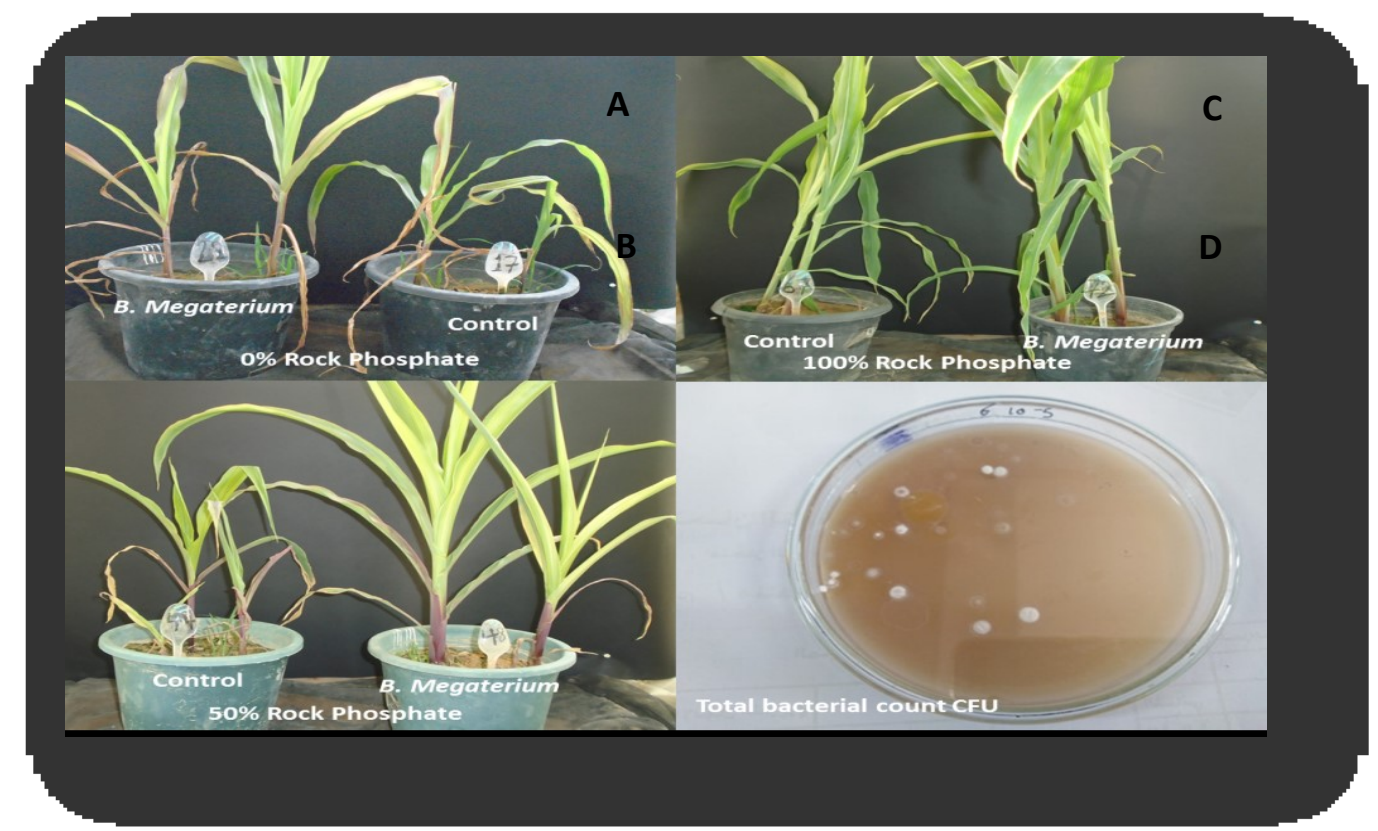

Figure (2). Schematic diagram of (A) Representative corn plants inoculated with Bacillus megaterium bacteria and un-inoculatd plants in the presence of rock phosphate with $0 \%$ level. (B) plants inoculated with Bacillus megaterium bacteria and un-inoculatd plants in the presence of rock phosphate with $50 \%$ level (C) plants inoculated with Bacillus megaterium bacteria and un-inoculatd plants in the presence of rock phosphate with $100 \%$ level .(D) Bacterial plates isolation for total count bacteria (CFU). All treatments without herbicide.

\section{B) Effect of rock phosphate, herbicides and phosphate solubilizing bacteria on Chemical composition}

It is evident from Table (4) that the different treatments showed a significant response to chemical characters. Data showed rock phosphate at $100 \%$ rate treatment recorded the highest chlorophyll index, maximum percentages of nitrogen, phosphorus and potassium (32.23 SPAD, 1.24, 0.60 and $1.48 \%$ ), as compared with control treatment which gave the lowest chlorophyll index, minimum percentages of nitrogen, phosphorus, and potassium (20.63 SPAD, 0.79, 0.38 and $0.94 \%)$, consequently.

The results recorded on nitrogen, phosphorus and potassium percentages presented are in Table (4), revealed that nano-herbicides significantly increased chlorophyll index (31.89 SPAD), nitrogen, phosphorus and potassium percentages (1.22, 0.59 and $1.46 \%$ ), as compared with control treatment which recorded the lowest chlorophyll index value (20.92 SPAD), least percentages of nitrogen, phosphorus, and potassium $(0.80,0.39$ and 0.96 $\%)$,It is clear from the obtained data in the same table that inoculation with phosphate solubilizing bacteria gave the highest chlorophyll index values, maximum percentages of nitrogen, phosphorus and potassium (27.59 SPAD, $0.95,0.51$ and $1.26 \%$ ), as compared with control treatment which recorded the 
lowest chlorophyll index, minimum nitrogen, phosphorus and potassium percentages (24.83 SPAD, 1.06, 0.46 and $1.13 \%$ ), respectively.

The interactions among rock phosphate and herbicides, rock phosphate and phosphate solubilizing bacteria were highly significant on nitrogen, phosphorus and potassium percentages. Also, the interaction between herbicides and phosphate solubilizing bacteria and the interaction between rock phosphate, herbicides and phosphate solubilizing bacteria were highly significant on nitrogen, phosphorus and potassium percentages and chlorophyll index. Kumar et al. (2001) suggested that the inoculation with bacteria capable to solubilize phosphates, phosphate rock which increases the availability of this element in the substrate, and as a consequence, increases its acquisition by the plant. The description above coincides with the results of the present study where it was shown that the use of phosphate rock as a source of $P$ in maize crops with the inoculation of bacterial strains can increase up to $10 \%$ the uptake of this element in comparison with the non-inoculated control supplied with phosphate rock. Phosphate solubilizing microorganisms solubilized $P$ to be available-P with its ability to secrete organic acids that can break complex $P$ compounds in the soil (Whitelaw, 2000).

The inoculation with microorganisms having phosphate solubilizing ability concurrently improved plant $P$ uptake and crop growth. This increase in growth may be attributed to auxin production (Gyaneshwar et al., 2002; Fankem et al., 2008), ACC-deaminase activity (Zafarul- Hye et al., 2007; Naik et al., 2008), production of organic acids (Fankem et al., 2008) or phosphatases (Abd-Alla, 1994; Chabot et al., 1996) to solubilize/mineralize $\mathrm{P}$, thereby increasing phosphate nutrition of inoculated plants. Similarly, Kapri and Tewari (2010) got increased shoot /root length, fresh and dry weight of shoot/root of chickpea due to inoculation with phosphate solubilizing and phosphatase producing Trichoderma sp. Similarly, Linu et al. (2009) found that Burkholderia sp. gave better results in improving the growth of cowpea and this strain had been previously evaluated by Pandey et al. (2005) to have phosphate solubilization, auxin production, ACC deaminase activity and also nitrogen-fixing ability.

\section{C) Total bacterial count cfu}

The samples were spread on Pikovskaya (PVK) agar plates which contained insoluble phosphate. Although bacterial counts were similar between the rhizosphere of the corn (approximately $1 \times 10^{6} \mathrm{cfu} \mathrm{ml}^{-1}$ ), the number of bacteria that created in the PVK aga, Figure (3) illustrated that the application of Bacillus megaterium increased the total bacterial count compared to the Uninoculated plants, however the total count of bacteria decreased in the high levels of rock phosphate but recorded a greater amount in case of nanoherbicide. The recorded data was agreed with (Zafarul-Hye et al., 2007; Naik et al., 2008). 
Table (4). Effect of rock phosphate, herbicides and phosphate solubilizing bacteria on chemical composition of corn plants

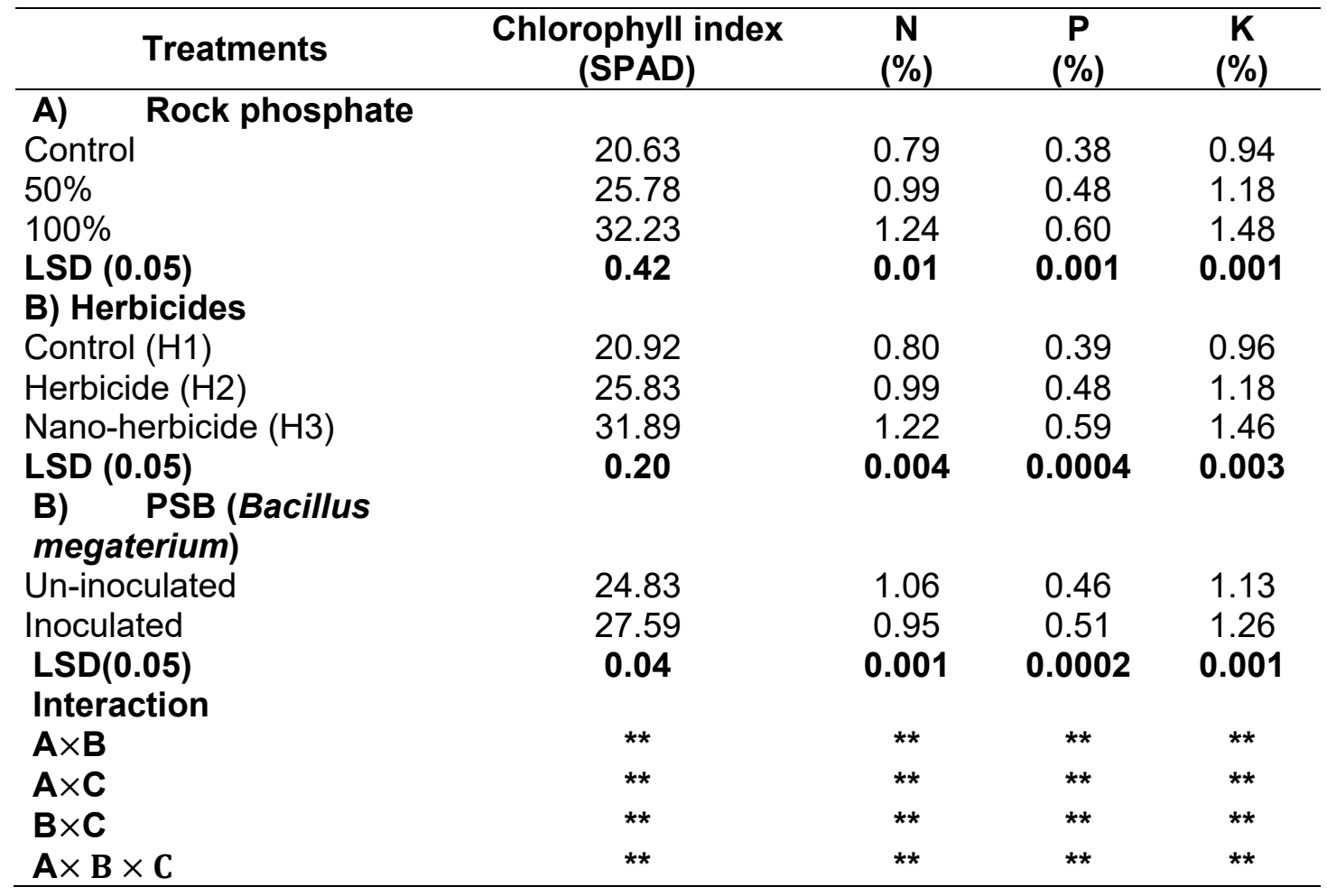

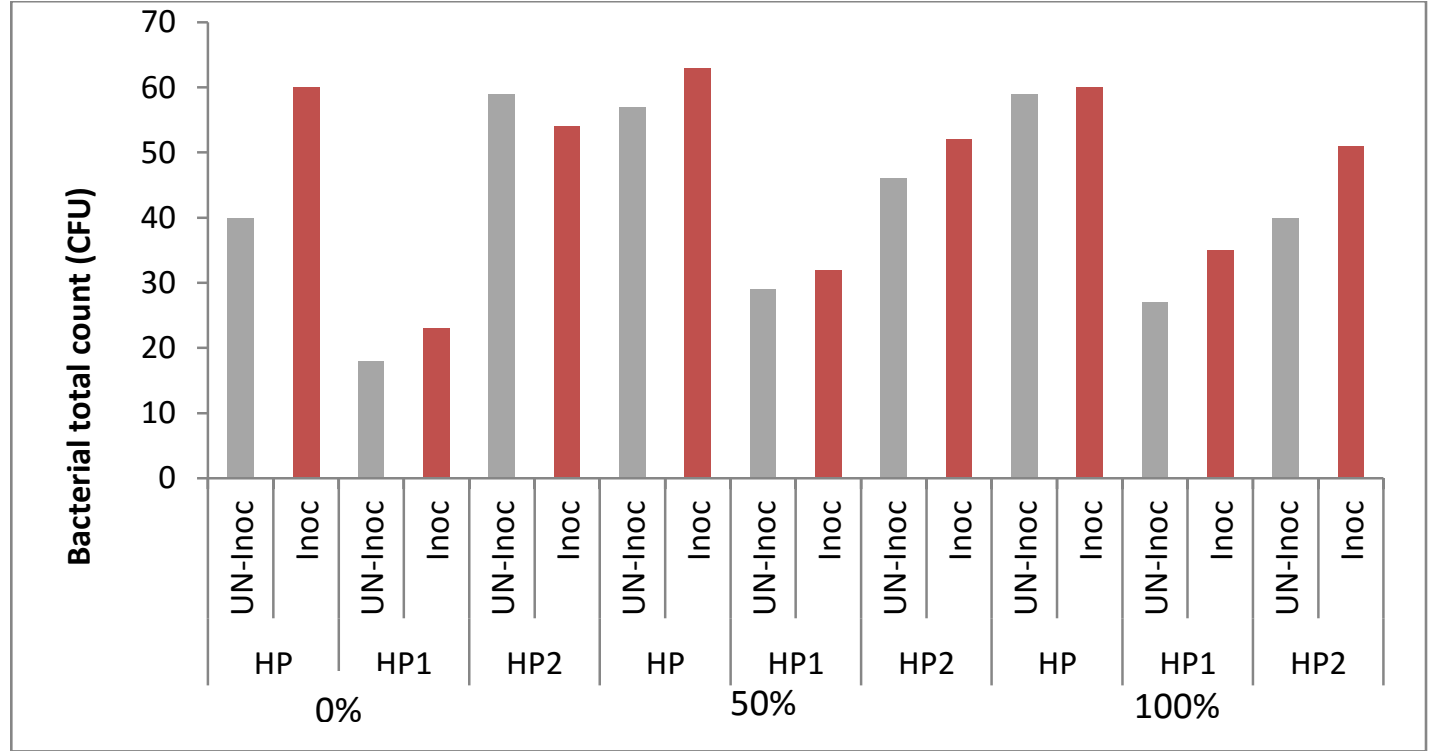

Figure (2b). Illustrate the total phosphate solubilizing bacteria and total count on PVK plate media, cfu taken with $10^{-6}$ concentration 


\section{RFERENCES}

Abd-Alla, M.H. (1994). Phosphatases and the utilization of organic $P$ by Rhizobium leguminosarum biovar viceae. Letter in Applied Microbiology, 18: 294-296.

Azziz, G., N. Bajsa, T. Haghjou, C. Taulé, A. Valverde and J. Igual (2012). Abundance, diversity and prospecting of culturable phosphate solubilizing bacteria on soils under crop-pasture rotations in a no-tillage regime in Uruguay. Appl. Soil Ecol., 61: 320-326.

Balaure, P.C., D. Gudovan and I. Gudovan, (2017). Nanopesticides: A new paradigm in crop protection. New Pestic. Soil Sens., 129-192.

Barea, J.M., M. Toro and R. Azcon (2007). The Use of 32P Isotopic Dilution Techniques to Evaluate The Interactive Effects of Phosphate-Solubilizing Bacteria and Mycorrhizal Fungi at Increasing Plant P Availability. In 'First International Meeting on Microbial Phosphate Solubilization' pp. 223227. (Springer).

Chabot, R., H. Anton and M.P. Cescas (1996). Growth promotion of maize and lettuce by phosphate-solubilizing Rhizobium leguminosarum biovar. phaseoli. Plant \& Soil, 184: 311-321.

Chapman, H. D. and P.F. Pratt (1978).Method of Analysis for Soil and Water. $2^{\text {nd }}$ Ed., Chapter, 17pp 150-161. Uni. Calif. Div. Agric. Sci. USA.

Cherr C. M., J. M. S. Scholberg and R. McSorley (2006). Green manure approaches to crop production. Agron. J., 98: 302-319.

Chien, S.H. and D.K. Friesen (1992). Phosphate rock for direct application In F.J. Sikora, ed. Future directions for agricultural phosphorus research, pp. 47-52. Bulletin Y-224. Muscle Shoals, USA, Valley Authority.

Collavino, M.M., P.A. Sansberro, L.A. Mroginski and O.M. Aguilar (2010). Comparison of in vitro solubilization activity of diverse phosphatesolubilizing bacteria native to acid soil and their ability to promote Phaseolus vulgaris growth. Biology and Fertility of Soils 46:727-738

Coutinho, F.P., W.P. Felix, A.M. Yano-Melo (2012). Solubilization of phosphates in vitro by Aspergillus spp. And Penicillium spp. Ecol. Eng., 42, 85-89.

Das, A.C. and S.C. Kole (2006). Effect of some root associative bacteria on germination of seeds, nitrogenase activity and dry matter production byriceplants. J. Crop Weed, 2: 47-51.

Das, A.C., A. Debnath and D. Mukherjee (2003). Effect of the herbicides oxadiazon and oxyfluorfen on phosphate solubilizing microorganisms and their persistence in rice fields. Chemosphere, 53: 217-21.

Eichler, M., C.E. Schnug and D.K. Ppen (2004). 'Soil Acid and Alkaline Phosphatase Activities in Regulation to Crop Species and Fungal Treatment'. Landbauforschung V 54, 01-05

El-Ghamry, A. M., C.Y. Huang and J.M. Xu (2001). Combined effect of two sulfonylurea herbicides on soil microbial biomass and $\mathrm{N}$ mineralization. J. Env. Sci., 13: 311-17.

Elser, J. and E. Bennett (2011). Phosphorus cycle: a broken biogeochemical cycle. Nat., 478 (7367): 29-31. 
Elser, J.J., M.E. Bracken, E.E. Cleland, D.S. Gruner, W.S. Harpole, H. Hillebrand, J.T. Ngai, E.W. Seabloom, J.B. Shurin and J.E. Smith (2007). Global analysis of nitrogen and phosphorus limitation of primary producers in freshwater, marine and terrestrial ecosystems. Ecol. Lett., 10(12):1135-1142.

Fankem, H., N.N. Laurette, D. Annette, Q. John, M. Wolfgang, E. FrançoisXavier and N. Dieudonné (2008). Solubilization of inorganic phosphates and plant growth promotion by strains of Pseudomonas fluorescens isolated from acidic soils of Cameroon. Afri. J. Microb. Res., 2: 171-178.

Flood, J. (2010). The importance of plant health to food security. Food Secur. 2, 215-231.

Frossard, E., M. Brossard, M.J. Hedley and A. Metherell (1995). Reactions controlling the cycling of $p$ in soils. In 'Phosphorus in the Global Environment'. (Ed H Tiessen) (SCOPE, John Wiley and Sons Ltd).

Gomez, K. A. and A. A. Gomez (1984).Statistical Procedures for Agricultural Research.John Wiley and Sons. Inc., New York.

Gressel, N. and J.G. McColl (1997). Phosphorus mineralization and organic matter decomposition: A critical review. In 'Driven by Nature: Plant Litter Quality and Decomposition'. (Eds G Cadisch, KE Giller) pp 297-309. (CAB International).

Han, H.S. and K.D. Lee (2005). Phosphate and Potassium Solubilizing Bacteria effect on Mineral Uptake, Soil Availability and Growth of Eggplant. Res. J. Agric. \& Biol. Sci., 1(2): 176-180.

Hayles, J., L. Johnson, C. Worthley and D. Losic (2017). Nanopesticides: A review of current research and perspectives. New Pestic. Soil Sens., 193-225.

lyamuremye, F., R.P. Dick and J. Baham (1996). Organic amendments and phosphorus dynamics: II. Organic Amendments and P Fractions. Soil Sci., 161: 436-443.

Jackson, M.L. (1973).Soil Chemical Analysis. Prentice-Hall of Englewood Clifs, New Jersy, pp: 925.

Kang, J., A. Amoozegar, D. Hesterberg and L. D. Osmond (2011). Phosphorus leaching in a sandy soil affected by organic and inorganic fertilizer sources. Geoderma. 161(3-4): 194--201.

Kapri, A. and L. Tewari (2010). Phosphate solubilization potential and phosphatase activity of rhizospheric Trichoderma sp. Brazilian J. Microb., 4:787-795

Khan, M.S., A. Zaidi and P.A. Wani (2007). Role of phosphate-solubilizing microorganisms in sustainable agriculture-A review. Agron. Sustain. Dev., 27: 29-43.

Khandelwal, N., R.S. Barbole, S.S. Banerjee, G.P. Chate, A.V. Biradar, J.J. Khandare and A.P. Giri (2016). Budding trends in integrated pest management using advanced micro-and nano-materials: Challenges and perspectives. J. Environ. Manag., 184: 157-169. Kochian 2012).

Kochian, L.V. (2012). Rooting for more phosphorus. Nature 488, 466-467

Kumar, V., R. K. Behl and N. Narula (2001). Establishment of phosphatesolubilizing strains of Azotobacter chroococcum in the rhizosphere and their effect on wheat cultivars under greenhouse conditions. Microbiol Res., 156: 87-93 
Lindsay, W. L. and W. A. Norvell (1978). Development of DTPA soil test for Zn, iron, manganese, and Copper. Soil. Sci. Soc. Am. J., 42:421-428.

Linu, M.S., J. Stephen and M.S. Jisha (2009). Phosphate solubilizing Gluconacetobacter sp., Burkhoderia sp. and their potential interaction with cowpea (Vigna unguiculata L.) Walp.). Int. J. Agric. Res., 4: 79-87.

Lowther, G. R. (1980). Using of single $\mathrm{H} 2 \mathrm{So}_{4}-\mathrm{H}_{2} \mathrm{O}_{2}$ digest for the analysis of pinusrediataneedles. Common Soil Sci. Plant Analysis.11: 175- 188.

Memon, K. S., A. Rashid and H.K. Puno (1992). Phosphorus deficiency diagnosis and $P$ soil test calibration in Pakistan. p.125. In: Proceedings of Phosphorous Decision Support System. College Station, TX.

Naik, P. R., G. Raman, K.B. Narayanan and N. Sakthivel (2008). Assessment of genetic and functional diversity of phosphate solubilizing fluorescent pseudomonads trains from rhizospheric soil. B.M.C. Microb., 8-230.

Nongthombam, S., H. Nayek and A.C. Das (2008). Effect of anilofos and pendimethalin herbicides on $\mathrm{N}_{2}$-fixing and phosphate solubilizing microorganisms in relation to availability of nitrogen and phosphorus in a Typic Haplustept soil. J. Crop \& Weed, 4(2): 1-6.

Oberson, D.K., Friesen I.M., S. Rao, K. Bühler and E. Frossard (2001). Phosphorus Transformations in an Oxisol Under Contrasting Land-Use Systems: The Role of The Soil Microbial Biomass. Plant \& Soil, 237: 197210.

Page, A.L., R.H. Miller and D.R. Keeney (1982). Methods of chemical Analysis" part 2: chemical and microbiological properties (second Edition ). American Society of Agronomy, Inc. and Sci. Soc. Of America, society of agronomy, Inc. and Sci. Soc. Of American, Inc. publishers, Madison , Wisconsin U.S.A.

Pandey, P., S.C. Kang and D. K. Maheshwari (2005). Isolation of endophytic plant growth-promotingg Burkhoderia sp. MSSP from root nodules of Mimosa pudica. Curr. Sci., 89: 177-180.

Penuelas, J., B. Poulter, J. Sardans, P. Ciais, M. van der Velde, L. Bopp, O. Boucher, Y. Godderis, P. Hinsinger, J. Llusia, E. Nardin, S. Vicca, M. Obersteiner and I.A. Janssens (2013). Human-induced nitrogenphosphorus imbalances alter natural and managed ecosystems across the globe. Nat. Commun., 4: 2934

Sinha, E., A. Michalak and V. Balaji, (2017). Eutrophication will increase during the 21 st century as a result of precipitation changes. Science, 357(6349): 405-408.

Steel, R. G. D. and J. H. Torrie (1982). Principles and Procedures of Statistics. 2nd Ed., McGraw Hill Book Co., Tokyo, Japan.

Stephenson, S.L. (2003). Myxomycetes of New Zealand. Fungal Diversity Press, Hong Kong, 238 pp.

Watson, D.J. (1952). The physiological basis of variation in yield. Advances in Agronomy, New York 4:101-145.

Whitelaw, M.A. (2000). Growth promotion of plants inoculated with phosphate solubilizing fungi. Adv. Agron., 69: 99- 151.

Wilhelm, J., M. F. Johnson, L. Karlen and T. David (2007). Corn stover to sustain soil organic carbon further constrains biomass supply. Agronomy J. 99: 1665-1667. 
Zafar-ul-Hye, M., Z.A. Zahir, S.M. Shahzad, M. Naveed, M. Arshad and M. Khalid (2007). Preliminary screening of rhizobacteria containing ACC deaminase for promoting growth of lentil seedlings under axenic condition. Pak. J. Bot., 39: 1725-1738.

Zak, D., T. Goldhammer, A. Cabezas, J. Gelbrecht, R. Gurke, C. Wagner, H. Reuter, J. Augustin, A. Klimkowska and R. McInnes (2018). Top soil removal reduces water pollution from phosphorus and dissolved organic matter and lowers methane emissions from rewetted peatlands. J. Appl. Ecol., 55, 311-320.

Zapata, F. and R.N. Roy (2004). Phosphate rock for sustainable agriculture. FAO Fertilizer and Plant nutrition Bulletin, Rome.

الملخص العربي

تأثير صخر الفوسفات وجسيمات مبيد الحشائش والبكتريا المذيبة للفوسفور علي النمو والمحتوي الكيماوي لنباتات الذرة المنزرعة في تربة جيرية

\section{'ماجدة أبوالمجد حسينَ 'أحمد عبد الفتاح محمود عبد المجيد ميادة علي صبرة؛} أحمدعمران المبروك نصر

'قسم الأراضي والكيمياء الزراعية - كلية الزراعة سابا باشا- جامعة الإسكندرية

r قسم وقاية النبات - كلية الزراعة سابا باشا- جامعة الإسكندرية

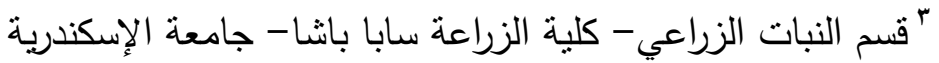

" طالب دراسات عليا

أجربت تجربة أصص على الذرة في الصوبة التجربيية لكلية الزراعة (سابا باشا) ، جامعة الإسكندرية، مصر ، لتقييم دور بعض مبيدات الحشائش ذات الجسيمات المتتاهية الصغر على نمو الذرة. ثم تصميم التجربة على أنها تصميم

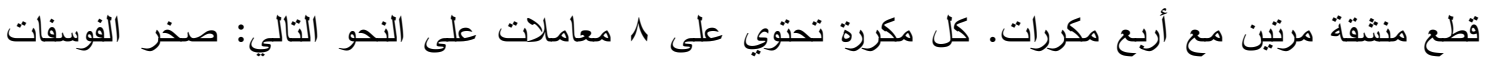
(كنترول، 0\%، . . 1\% م الجرعات الموصي بها) مبيدات الحشائش (كنترول، مبيدعادي، مبيد النانو) ، والبكتريا

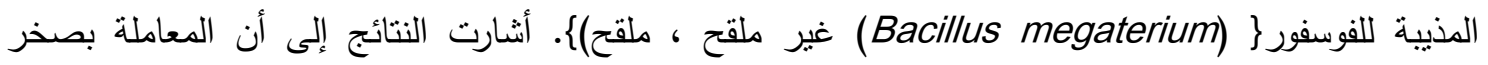
الفوسفات بتركيز . 1\%، مبيد النانو والبكتيريا سجلت أعلى منتسط لقيم الصفات الخضرية منل ( إرتفاع النبات

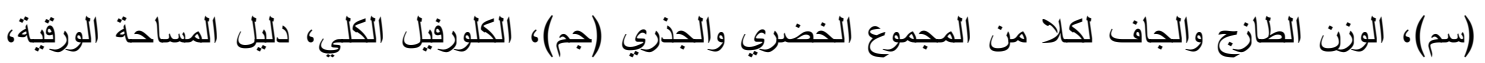
وذلك مقارنة بالكنترول الذي أعطي أقل القيم لهذه الصفات، كذلك سجلت المعاملة بصخر الفوسفات بالمعدل • . 1\%، مبيد النانو والبكتيريا أعلي القيم للوزن الطازج والجاف للجذر مقارنة بالنباتات غير المعاملة، من ناحية

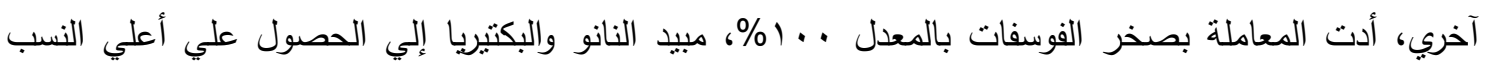
المئوية لكل من النيتروجين والفوسفور والبوتاسيوم في الأوراق، مقارنة بمعاملة الكنترول وبقية المعاملات الآخرى. 